\title{
Palaeoecology and conservation of endangered hidden species; example of the liverwort Riella (Riellaceae)
}

\author{
Morteza Djamali $^{1,2}$ [D . José Gabriel Segarra-Moragues ${ }^{3}$
}

Received: 28 January 2021 / Revised: 23 May 2021 / Accepted: 25 May 2021

\begin{abstract}
Palaeoecology is increasingly contributing to conservation biology and restoration ecology by extending the recent annual to decennial records of ecological observations to centennial and millennial time scales. One of the almost neglected potential applications of palaeoecological investigations in conservation biology is the discovering of hidden species in subrecent fossil records. Such discoveries can be common in biodiversity hotspots in which the fauna and flora are not still fully known. In this study, we present the case of the liverwort Riella in continental southwest Asia (Iranian plateau), a very vulnerable taxon growing and reproducing under very special ecological circumstances. Our study adds two new species of Riella ( $R$. echinata and $R$. helicophylla) in addition to the formerly reported $R$. cossoniana, to the subfossil bryophyte flora of Iran. We demonstrate the important contribution that the genus has played in the history of wetland flora of the semi-arid to arid areas of Iran during the late Quaternary. We further demonstrate the possibility that it is still thriving in many wetland systems and may need to be discovered and then protected in its potential habitats. We suggest that in the biodiversity hotspots of lower latitudes, more attention has to be paid to taxonomic identification of species to reveal the hidden part of the biodiversity for defining better conservation strategies for vulnerable aquatic ecosystems such as the seasonal wetland systems.
\end{abstract}

Keywords Conservation biology $\cdot$ Seasonal wetlands $\cdot$ Bryophytes $\cdot$ Semi-arid regions $\cdot$ Southwest asia

Communicated by T. G. Allan Green.

Morteza Djamali

morteza.djamali@imbe.fr

José Gabriel Segarra-Moragues

J.Gabriel.Segarra@uv.es

1 Institut Méditerranéen de Biodiversité et d'Ecologie - IMBE (Aix Marseille Univ, Avignon Université, CNRS, IRD), Europôle de l'Arbois, 13545 Aix-en-Provence, France

2 Iranian National Institute for Oceanography and Atmospheric Sciences (INIOAS), 3 Etemad Zadeh St., Fatemi Ave, 14155-4781 Tehran, Iran

3 Departamento de Botánica y Geología, Facultad de Ciencias Biológicas, Universitat de València. C/Dr, Moliner s/n, 46100 Burjassot, Valencia, Spain 


\section{Introduction}

\section{Background and objectives}

It is becoming increasingly evident that palaeoecology can effectively contribute to conservation biology and restoration ecology by providing long-term records of ecological changes and extending the ecological observations into longer decadal to millennial time scales (Birks 1993, 2012; Jackson and Hobbs 2009; Willis et al. 2010). There are a number of ways palaeoecological data can aid the managers to conserve, maintain, and even restore the biodiversity, ecosystems, and resources (Froyd and Willis 2008; Jackson and Hobbs 2009; Wingard et al. 2017). Some common examples of palaeoecological applications in biological conservation are to (i) understand biological invasions (Jackson 1997; Froyd and Willis 2008), (ii) reconstruct biodiversity dynamics and dynamic equilibrium between extinction, migration, and persistence (Jackson and Overpeck 2000; Froyd and Willis 2008), and (iii) detect 'cold-stage refugia' or 'glacial refugia' as well as 'warm-stage refugia' or 'interglacial refugia' as priority conservation targets (Willis et al. 2010).

As an example, as far as the biological invasion is concerned, palaeoecological studies can establish if a particular species of conservation concern is native, non-native or 'alien' in a given ecosystem or landscape (Jackson 1997; Willis and Birks 2006; Birks 2012). Such studies can further assess the long-term impact of 'alien' species on the structure and functioning of an ecosystem (Froyd and Willis 2008). Interesting examples of palaeoecology elucidating the origin of 'doubtful natives' and helping conservation management, can be found in oceanic islands colonized by humans during the last centuries with introduction of exotic species threatening the local fauna and flora (Leeuwen et al. 2008; Coffey et al. 2011).

There is however, another potential of palaeoecology to serve conservation biology which has so far been underexplored by both conservationists and palaeoecologists. The basic idea is that in rich biogeographical territories, such as biodiversity hotspots, in which the biodiversity is still not fully known, palaeoecological data can reveal the hidden taxa which presence has not yet been evidenced by scientists. These are almost certainly present in the ecosystem and are potentially of high conservation value. Palaeoecological records of recent past are particularly valuable to give promising evidence of such taxa still thriving in a given ecosystem.

To exemplify this, we use the liverwort genus Riella in continental SW Asia as our model (see below). The long-term ecological history of Riella can be inferred from its fossil spores trapped and preserved in wetland sediments (Djamali et al. 2008a, b). This study aims to present palaeoecological records of Riella in numerous published and unpublished pollen records from Iran. It will provide a spatio-temporal distribution pattern for the genus in one of the significant biodiversity hotspots of Northern Hemisphere. It will also demonstrate how palaeoecological insights can help design preventive strategies to conserve these liverworts and their habitat in an alarmingly changing world.

\section{Geographical and bioclimatic setting}

The study area is located in the continental interior of southwest Asia mainly corresponding to the Zagros Mountains, a NW-SE oriented high mountain system stretching $>1500 \mathrm{~km}$ from the Anatolian plateau to the Gulf of Oman (Figs. 1, 2). 

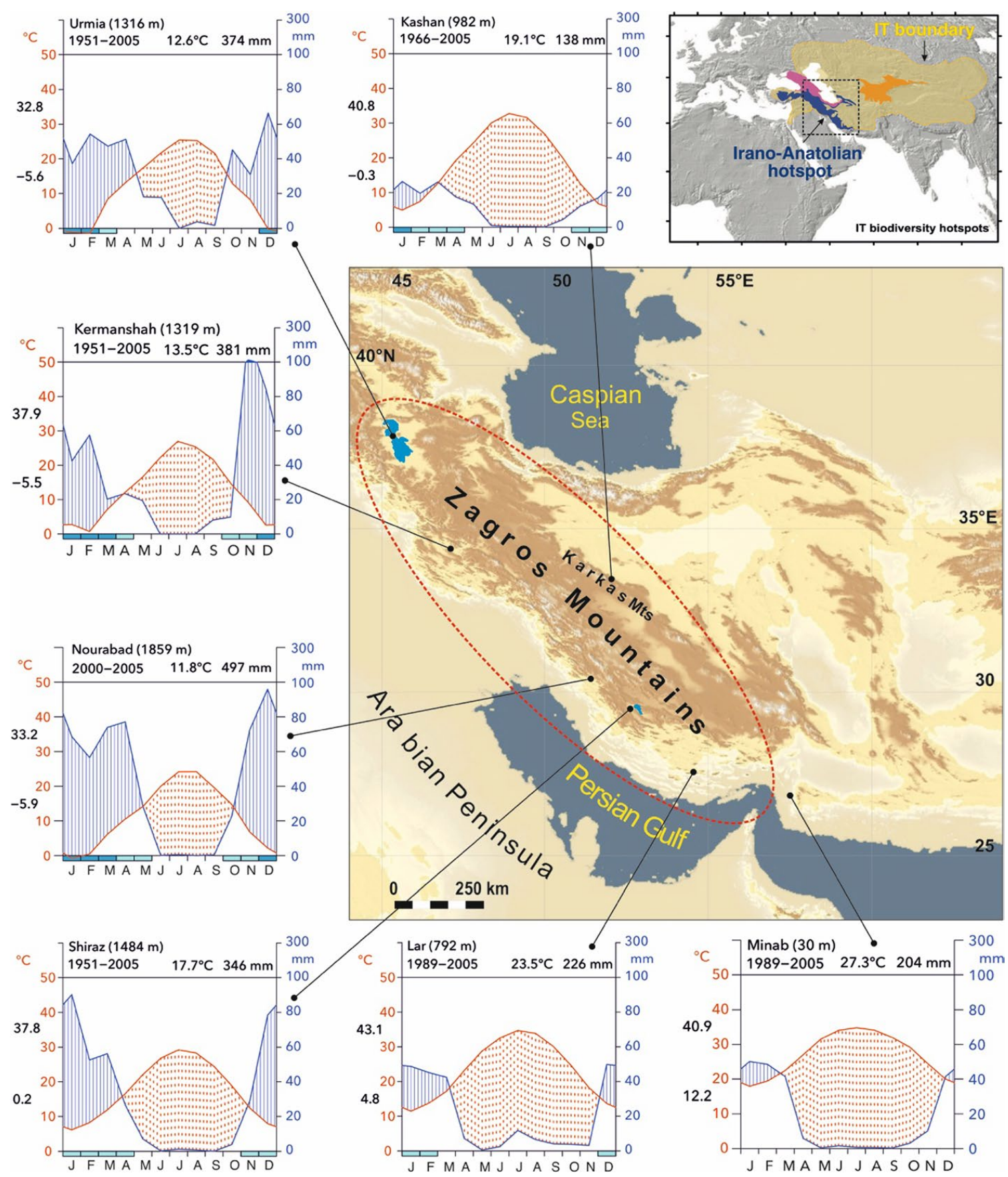

Fig. 1 The study area limited to the Zagros Mountains in western Iran (see Fig. 2 for the location of the study sites). Upper-right inset map presents the location of the Irano-Anatolian biodiversity hotspot (in blue) within the Irano-Turanian floristic region (After Manafzadeh et al. 2016). IT: Irano-Turanian. Note the Mediterranean precipitation regime reflected in climate diagrams of Zagros with increasing tropical character moving from northwest to southeast. Climate diagrams are created in 'Climatol' package (Guijarro 2019) in RStudio (RStudio Team 2015) based on data from Iran Meteorological Organisation. In climate diagrams, the left $\mathrm{Y}$-axis represents the temperature in ${ }^{\circ} \mathrm{C}$ and the right $\mathrm{Y}$-axis represents the precipitation in $\mathrm{mm}$. Next to the $\mathrm{X}$-axis, mean daily maximum temperature of the warmest month and mean daily minimum temperature of the coldest month are also written. Blue and red curves represent the precipitation and temperature, respectively. Blue-shaded areas represent the wet season $(\mathrm{P}>2 \mathrm{~T})$ and red-shaded areas show the dry season $(\mathrm{P}<2 \mathrm{~T})$. Blue bars on $\mathrm{X}$-axis show the months with likely frost

This area is dominated by the 'Irano-Turanian bioclimate' which is a continental variant of the Mediterranean bioclimate with higher continentality, more marked precipitation seasonality and longer summer droughts (Djamali et al. 2011, 2012a). In the true 


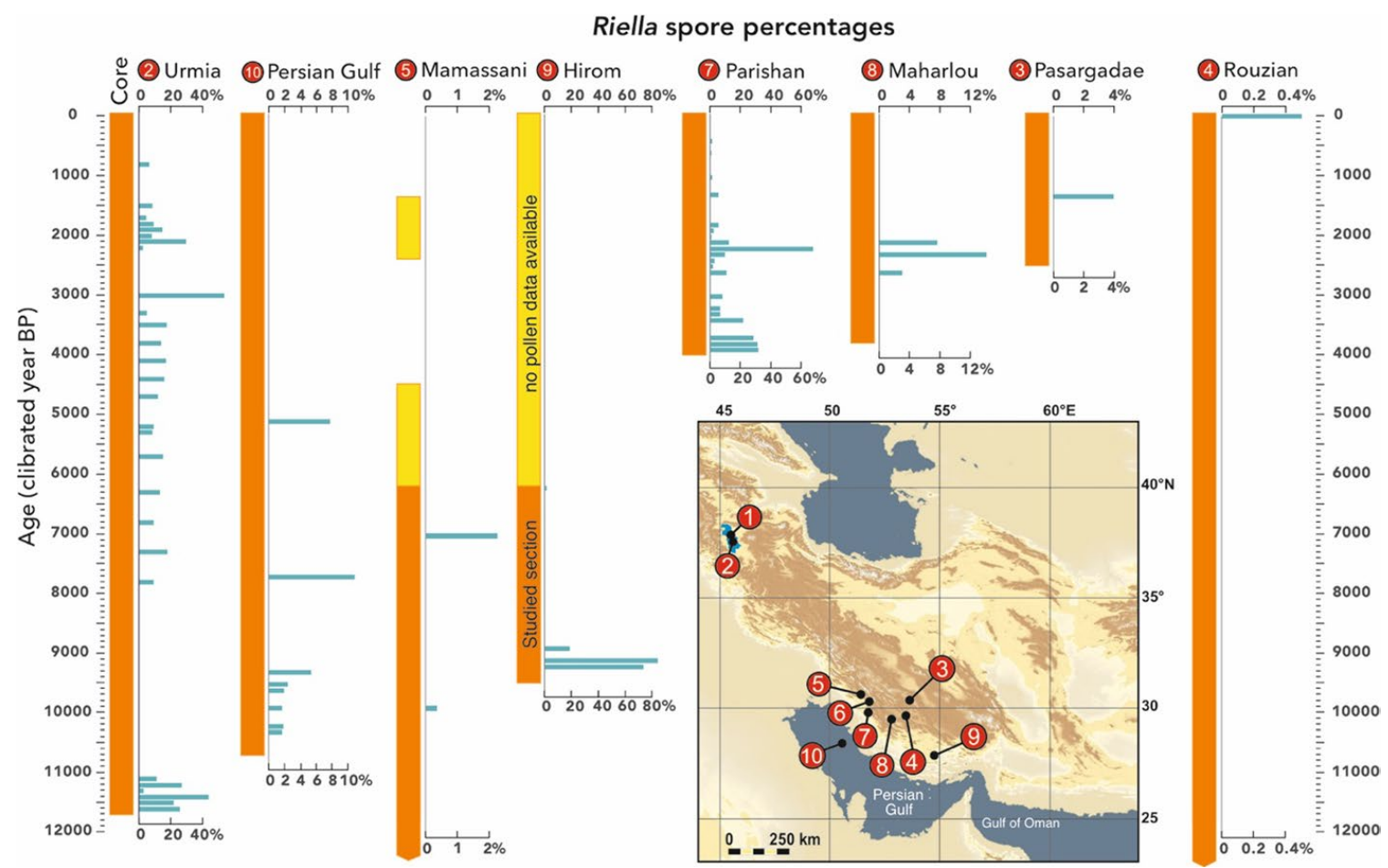

Fig. 2 Palaeoecological records of Riella spores in two cores from Lake Urmia (NW Iran) and eight sites in the Zagros Mountains and the Persian Gulf in SW Asia. Spore sequences are arranged from oldest (left) to youngest (right) recorded appearance of the spore. Riella spore percentages represented by blue bars have been calculated on the sum of all aquatic pollen and spores (including Riella). The columns represent the sediment cores. Those sections of the cores studied by pollen analysis are shown in orange and those sectons not analysed for pollen are shown in yellow. Please note that the horizontal axes (spore percentages) are not on the same scale in order to give more visibility to those sites with lower values for Riella spores

Mediterranean world, this climate is equivalent to three rare bioclimatic types called 'Mediterranean pluviseasonal-continental', 'Mediterranean xeric-continental', and 'Mediterranean desertic-continental' according to the Global Bioclimatic Classification (RivasMartínez et al. 2005). A number of climate diagrams from the study area are illustrated in Fig. 1. A common feature of most of these diagrams is the long duration of the dry season defined as those months during which the precipitation $(\mathrm{P})$ is less than two times the temperature $(\mathrm{T})(\mathrm{P}<2 \mathrm{~T})$, lasting from 5 to 8 months with precipitation mainly falling from October to April.

The very seasonal distribution of annual precipitation and strong evaporation during the long summer months have given a very ephemeral character to Iranian wetland systems with a high amplitude of water-table fluctuations making them vulnerable ecosystems to ongoing global change (Mousaei-Sanjerani and Rundel 2016). Indeed, most of the Iranian internal lake systems are playa lakes with substantial annual, decadal, and longer-term hydrological fluctuations, alternatively flooding and exposing vast expanses of shallow lake environments in response to hydroclimatic variations (Krinsley 1970; Mousaei-Sanjerani and Rundel 2016).

The study area falls into the western Irano-Turanian floristic region (Fig. 1: upper right inset map), one of the largest and richest phytogeographical regions of the world (Djamali et al. 2012a; Manafzadeh et al. 2016). The vegetation in mostly composed of IranoTuranian montane steppes and steppe-forests with Quercus brantii, Pistacia atlantica, Acer monspessulanum, and arboreal Rosaceae dominating (Zohary 1973). 


\section{Model taxon: Riella}

The family Riellaceae (Marchantiophyta, Sphaerocarpales) consists of two genera, the monotypic Austroriella, known only from a single locality in Australia (Cargill and Milne 2013) and Riella, with a world-wide distribution (except Antarctica) and 29 taxa (Söderström et al. 2016, Table 1). The majority of the Riella populations are found in areas of Mediterranean-type and subtropical semi-arid climates with a marked precipitation seasonality and develop in seasonally flooded shallow lake and wetland environments (Gradstein 2016; Sabovljević et al. 2016). Riella species have very small and disjunct populations mostly distributed in the Mediterranean bioclimatic areas of the world (e.g. Segarra-Moragues and Puche 2014; Segarra-Moragues et al. 2012; Cargill and Milne 2013; Gradstein 2016). Our knowledge on the taxonomy and conservation status of Riella is however, still limited due to rare sights of living species in nature and their poorly-known global spatial distribution (Geissler 2001; Segarra-Moragues et al. 2014). The latter fact is evident by description of several new species and new records over the last decade across the world (Segarra-Moragues et al. 2012; Cargill and Milne 2013; Puche and Segarra-Moragues 2013; Segarra-Moragues and Puche 2014; Segarra-Moragues et al. 2019a, b).

Table 1 presents 29 taxa recognised at the species rank or below of the Riellaceae family (Söderström et al. 2016). Of these, eight taxa (27.6\%) have been designated of having unresolved taxonomic status, indicating a significant gap of taxonomical knowledge. Such lack of knowledge extends also to their conservation status. The conservation status of 11 (37.9\%) of the 29 taxa has not been assessed yet, whereas conservation assessments are available for $14(48.3 \%)$ and $4(13.8 \%)$ for their global and partial distribution ranges, respectively. Notwithstanding, eight (57.1\%) out of the 14 globally assessed taxa have been assessed as Data Deficient (DD), indicating a significant lack of knowledge on the status of their populations. The remaining six taxa have been assessed as Extinct (R. spiculata), Critically Endangered (R. affinis), Endangered (R. bialata and R. echinata) and Vulnerable (R. heliospora and R. mediterranea, Table 1). Riella cossoniana, the only species which fossil/subfossil spores have so far been reported from SW Asia (Djamali et al. 2008b) is considered as DD globally, Nearly Threatened in its European range and as Vulnerable in Spain, where most of the currently known populations have been reported in recent times (Segarra-Moragues et al. 2014, Table 1). In summary, the conservation status of the majority of the Riella taxa remains still obscure because of the missing information on the population biology, ecology and distribution of their extant populations around the world (Table 1).

\section{Materials and methods}

\section{Palaeoecological archives}

In this paper we present 10 palaeoecological records of Riella spores extracted from pollen diagrams (Fig. 2; Table 2). All diagrams come from western highlands of the Iranian plateau (Fig. 2 inset map). The presence of Riella spores has been so far reported and published from only three sites i.e. Lake Urmia (Djamali et al. 2008b; Talebi et al. 2016), Lake Parishan (Djamali et al. 2015), and Lake Maharlou (Saeidi Ghavi Andam et al. 2020). Most of the fossil spore data presented in this paper are thus, the first records of Riella from the 


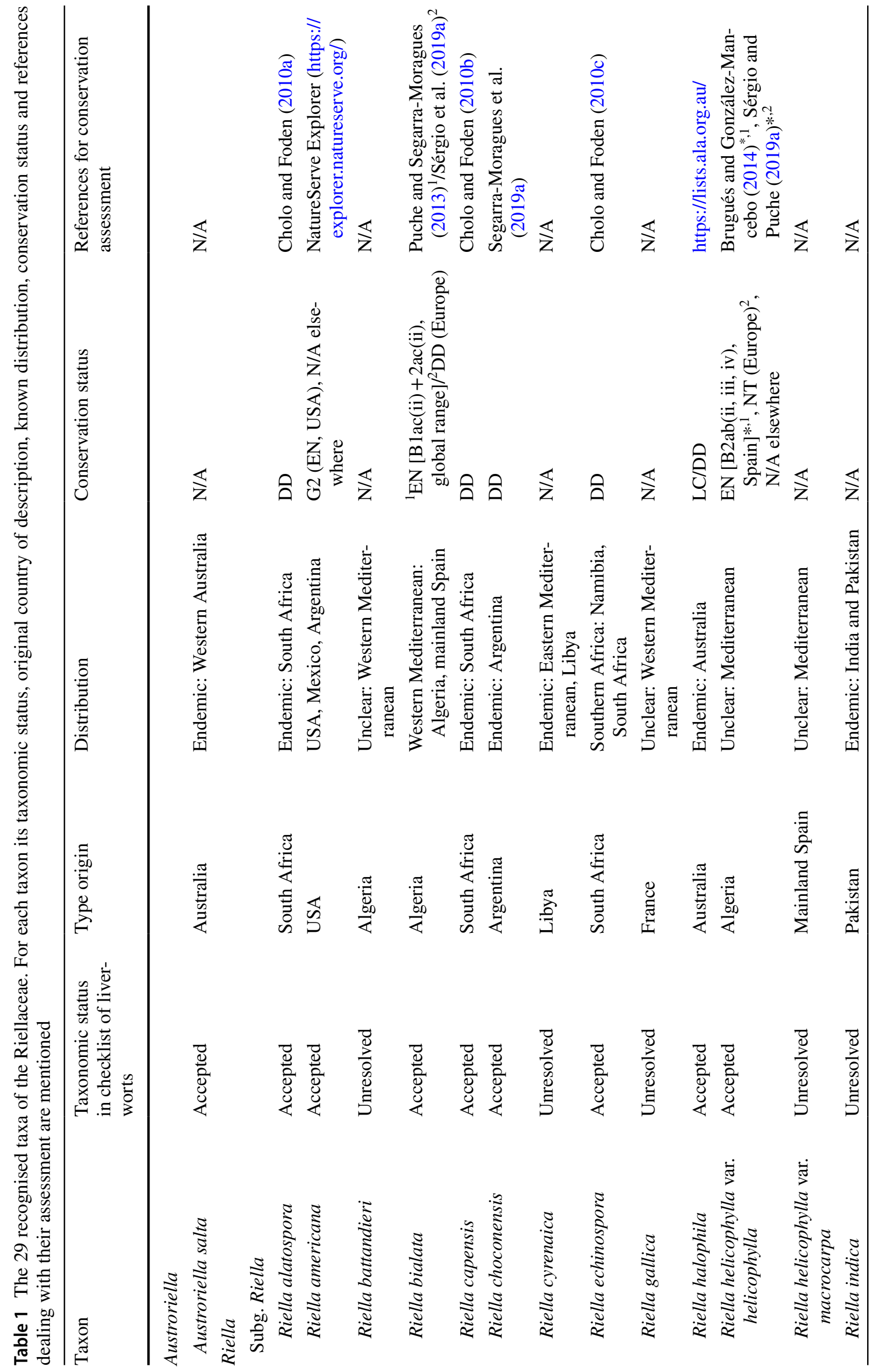




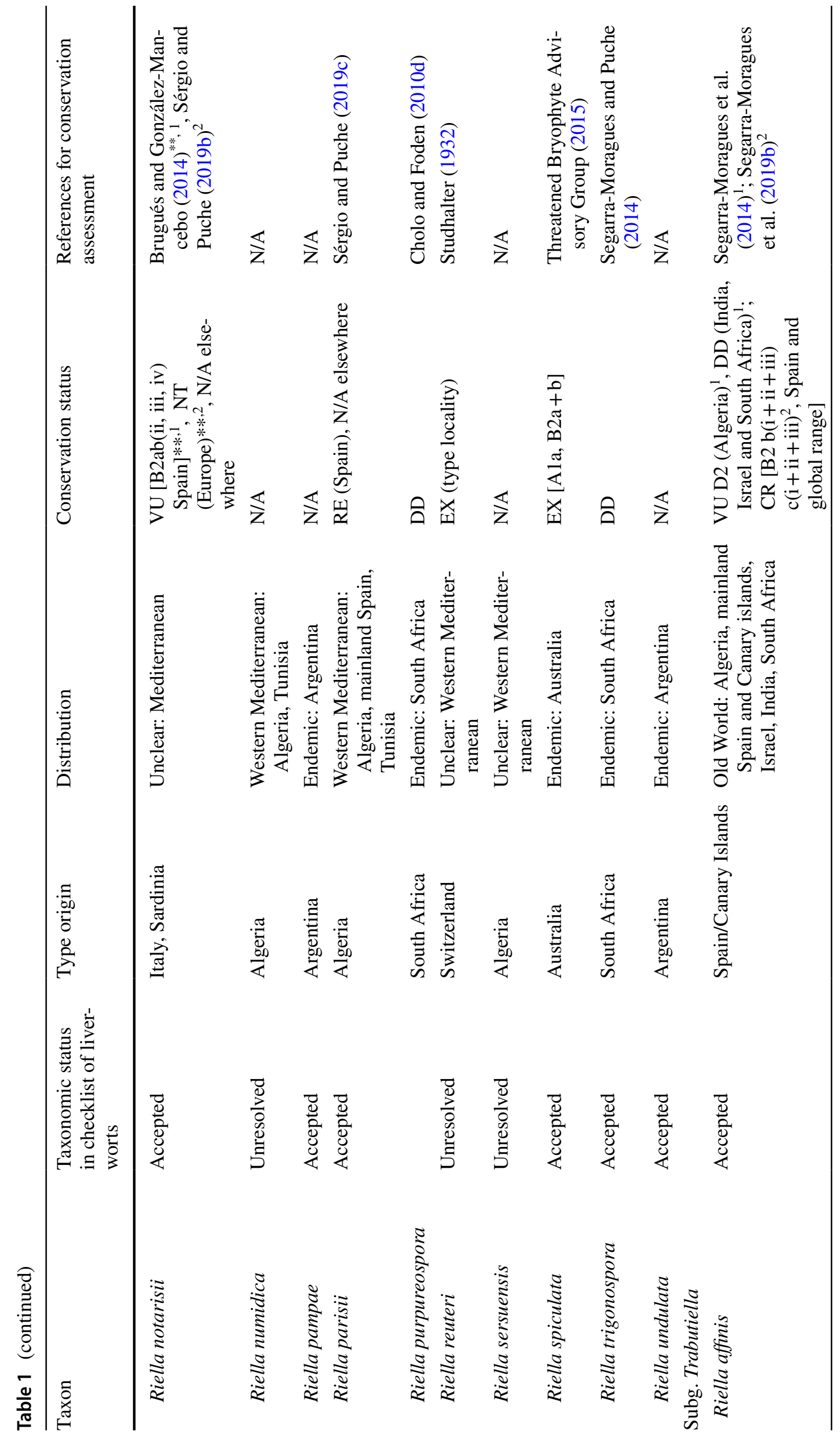




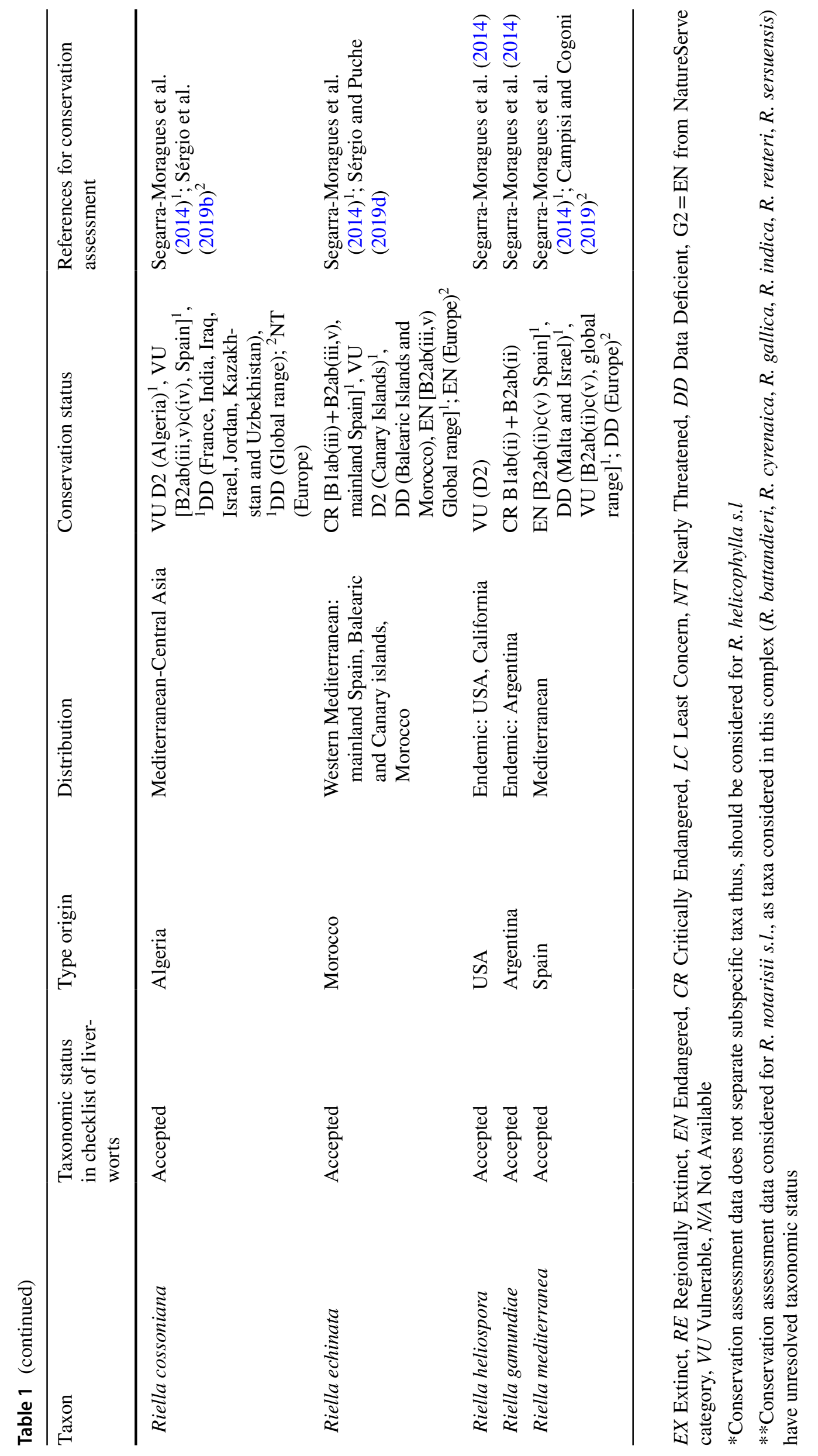




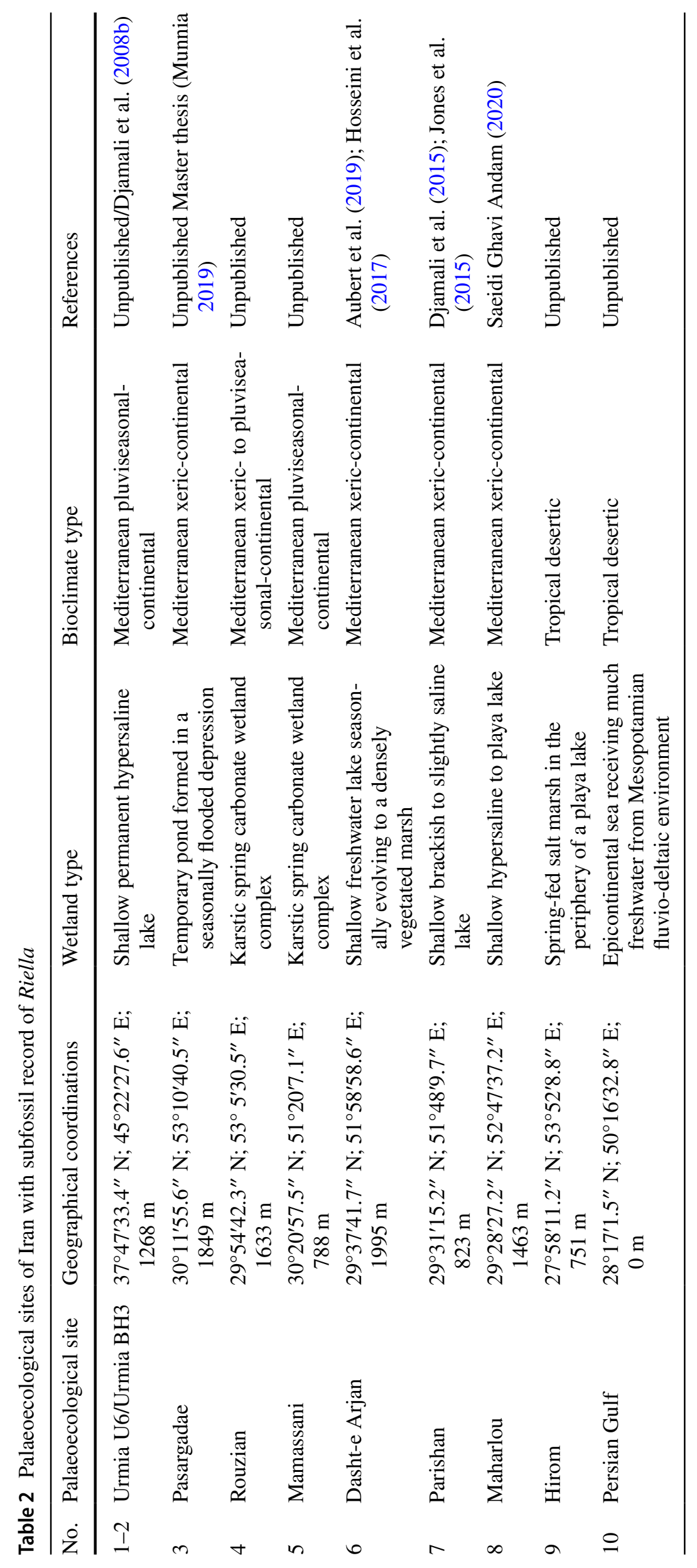


area (e.g. Pasargadae, Rouzian, Mamassani, Hirom, and Persian Gulf, Table 2). Pollen and spores have been extracted from wetland sediment cores using the classical extraction technique described in Moore et al. (1991) and Riella spores have been counted and identified under $\times 500$ magnification. Representative samples were also observed and photographed by Scanning Electron Microscopy (SEM) following the procedures described in SegarraMoragues et al. (2014) on a Hitachi S-4800 at the Servei Central de Suport a la Investigació Experimental (SCSIE) at the University of Valencia. Their percentage values have been calculated over the sum of the pollen of aquatic plants (hydrophytes and helophytes) and plotted against an absolute chronological scale. The percentages of Riella spores in Urmia BH3 core were calculated on total pollen of terrestrial plants to be comparable with data presented in the original publication (Djamali et al. 2008b). All sediment cores have been dated by radiocarbon dating except for the site of Pasargadae which has been dated by Optically Stimulated Luminescence (OSL) dating (Munnia 2019). The radiocarbon ages of the sites 3, 4, 5, 9, and 10 can be found in Supplementary Materials (S1) and those of Maharlou and Parishan records (7 and 8 in Fig. 2) can be found in Brisset et al. (2019) and Djamali et al. (2015), respectively. Age-depth model of Holocene Urmia U6 record (2 in Fig. 2) has been provided by Dr. Arash Sharifi, University of Miami, USA. For the long core of Urmia BH3, a re-tuning of the record was performed by correlating the arboreal pollen variations (Djamali et al. 2008b) to a recently published high resolution speleothem stable isotope record covering the whole Marine Stable Isotope Stage 5 (Mehterian et al. 2017). Absolute concentrations of Riella spores were calculated using Lycopodium spore counts following Stockmarr (1971). All age-depth models have been established or re-established in 'clam' package (Blaauw 2010) in RStudio version 3.5.3 (RStudio Team 2015).

\section{Results}

\section{Riella, a significant bryophyte in the late Quaternary flora of Iran}

Subfossil spore records of Riella presented in Figs. 2 and 3 cover a wide spatio-temporal scale (Fig. 2). Spatially, they are found in 10 sites spread along a $1300 \mathrm{~km}$ transect from northwestern corner of Iran in hypersaline lake Urmia to the southernmost part of the country in the Persian Gulf (Fig. 2). Temporally, the records go back at least to 195,000 years ago at the very end of the Marine Isotope Stage 7 (Fig. 3) and end at contemporaneous sediments in Rouzian wetland (4 in Fig. 2) as well as in Lake Urmia (Talebi et al. 2016). The occurrences and frequency changes of Riella spores follow a very fluctuating pattern. While some records such as Lake Parishan (Record 7 in Fig. 2, Table 1) reveal Riella spores in most of the studied spectra, others display Riella spores in only a few spectra (e.g. 3, 4, and 5 in Fig. 2).

Currently, the common feature of most of the above palaeoecological sites is the presence of shallow water environments with high water-table fluctuations (Table 2). Some of the sites are large brackish water to saline lake systems with substantial annual or interannual water level fluctuations (e.g. Lake Urmia, Lake Maharlou, Lake Parishan, Dasht-e Arjan Wetland; Djamali et al. 2008a, b; Jones et al. 2015; Aubert et al. 2019; Brisset et al. 2019). Although the main water bodies are saline to hypersaline, there are abundant freshto brackish water shallow wetlands formed on the fluvio-lacustrine environments, formed at the entrance of river systems or along the springs fed by karstic systems or seepage from 


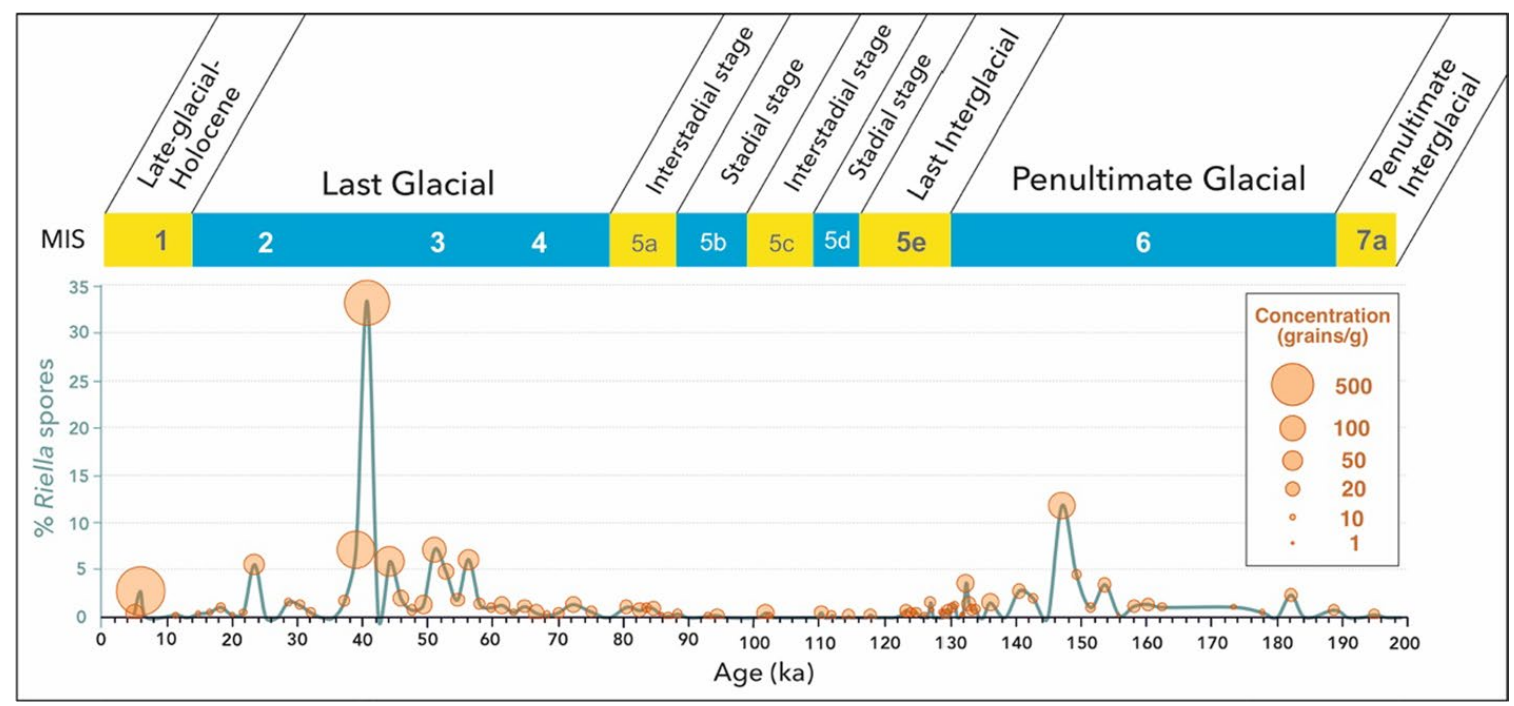

Fig. 3 Riella spore percentages and concentrations in a 200,000 years old sediment core from Lake Urmia, NW Iran. Note that higher concentrations do not necessarily correspond to higher percentages and that highest peaks occur during the glacial periods rather than interglacial periods

alluvial fan fringes (Frey and Probst 1974; Djamali et al. 2008a, 2009a; Brisset et al. 2019). Others are shallow wetlands mainly fed by karstic springs e.g. Rouzian (Djamali et al. 2018), Hirom, and Mamassani (Fig. 2). Rouzian is one of the numerous carbonate wetlands formed at the emerging point of karstic springs creating a wetland complex composed of a patchy landscape of subaerially exposed and inundated areas (Djamali et al. 2018). Some smaller wetlands and ponds form due to seasonal flooding by snowmelt and surface runoff e.g. in Pasargadae. The Riella spores found in a Persian Gulf core indicate the presence of Riella in the wetland systems frequently formed on the fluvio-deltaic environments in southern Mesopotamia in Iraq and southwestern plains and lowlands in Iran (Fig. 1). Higher abundance of Riella spores in the early Holocene sediments of the Persian Gulf (10 in Fig. 2) may indicate that Mesopotamian fluvio-deltaic environments were located much further to the east closer to the coring site when the Persian Gulf floor was still partially exposed before the global sea level rise (Uchupi et al. 1999).

The longest record of Riella in Iran comes from Lake Urmia, a permanent hypersaline lake in northwestern Iran in which Riella spores have been found in 83 over 131 pollen spectra covering the last 200,000 years (Djamali et al. 2008a, b). The record has already been published and discussed in Djamali et al. (2008b) but is here reanalysed with the addition of spore concentration values (Fig. 3). Riella spore percentages display their highest peaks during the penultimate (MIS 6) and last glacial periods (MS 3) with lowest values mostly corresponding to interglacial and interstadial intervals (e.g. MIS 5e) (Fig. 3). This fact suggests that populations of Riella in Urmia have not been very sensitive to lower temperatures of the last glacial periods but, have mostly been controlled by hydrological variations (Djamali et al. 2008b). Absolute concentration values (total number of spores per gram of dry sediment) also showed a similar trend with higher concentrations correlating to higher percentages. This correlation indicates that spore production was truly higher during the above intervals with some samples containing $>100$ spores/g which in turn suggests dense populations of the liverwort colonizing abundant shallow wetland environments. One sample peaking at around 6000 years ago surprisingly contained $>500$ Riella spores while presenting only $2.7 \%$ of total terrestrial pollen. Such examples indicate that the presence of these liverworts 
may be underestimated if one only judges on the relative frequency changes of the spores. In BH3 pollen record, Riella spore percentages almost perfectly covary with pollen percentage values of freshwater to brackish water aquatic plants (Sparganium, Typha, and Cyperaceae) indicating that the suitable habitats for Riella have been provided during periods of higher lake levels and less saline environments on the vast seasonally flooded shallow lake environments and wetland systems (Djamali et al. 2008b). More recently, Riella spores have also been recorded in late Holocene sediments from a small spring-fed wetland merging into the SW shores of the lake (Talebi et al. 2016). Youngest spore occurrences date back to less than one century, strongly suggesting that the species may still be thriving in similar environments.

Outside the SW Asia, the few pre-Quaternary findings of Riella spores go back to Eocene to Miocene sediments of Iberian Peninsula and Argentina showing the presence of this plant in the wetland environments of both European and American continents (Cavagnetto and Anadón 1996; Quattrocchio et al. 2003). The Quaternary record of Riella spores is also rare and is limited to a few pollen records from Spain, Asia and South America. One example is a recent publication from Doñana National Park in southern Spain in which Riella spores (cf. R. helicophylla and R. cossoniana) have been identified in a Holocene pollen record (Manzano et al. 2018). However, that record has not been commented by the authors. A single peak of Riella spores has also been recorded in a pollen diagram from Southern Tibet (China) and has been interpreted as indicator of soil salinisation caused by ineffective irrigation of cereal fields (Miehe et al. 2006). It has also been reported, with limited occurrence, in one Argentinian pollen diagram (Prieto and Quattrocchio 1993). Riella in the above fossil pollen records shows similar patterns to Iranian records in that the spores appear as sporadic discontinuous curves with very variable abundances.

\section{Taxonomic diversity of fossil Riella in Iran}

Light microscopic and Scanning Electron Microscopy of the Riella spores extracted from Iranian samples surprisingly revealed at least three different species (Fig. 4), namely $R$. cossoniana, $R$. echinata and $R$. helicophylla. So far, only one subfossil species i.e. $R$. cossoniana had been described from Lake Urmia (Djamali et al. 2008a). In this study we add $R$. echinata (Fig. 4D-F) and R. helicophylla (Fig. 4G-L) new to the Iranian subfossil flora. Riella echinata is a rare species, so far known from the Western Mediterranean (Mainland Spain, Balearic Islands, and Morocco) and the Canary Islands (Segarra-Moragues et al. 2014). Therefore, our results may suggest either a broader distribution in the Mediterranean area or alternatively a relict status of the current populations in the western Mediterranean. In Lake Hirom, the spore morphology matches Riella helicophylla (Fig. 4G-L). This species includes var. macrocarpa P. Allorge, a variety that has been barely recognised in reports following its description (Allorge 1929) and that needs further taxonomic study. Notwithstanding, the spore morphology observed here matches that taxon. Riella helicophylla has a broad distribution in the Mediterranean area with most of its records concentrated in the western Mediterranean. Few, mostly old records have been reported from Israel (Lipkin and Proctor 1975) and Turkey (Kürschner and Erdağ 2005). Thus, the Iranian record may indicate this species could be much more widespread in Asia, than previously thought, as reported for $R$. cossoniana and $R$. affinis (Segarra-Moragues et al. 2014). 


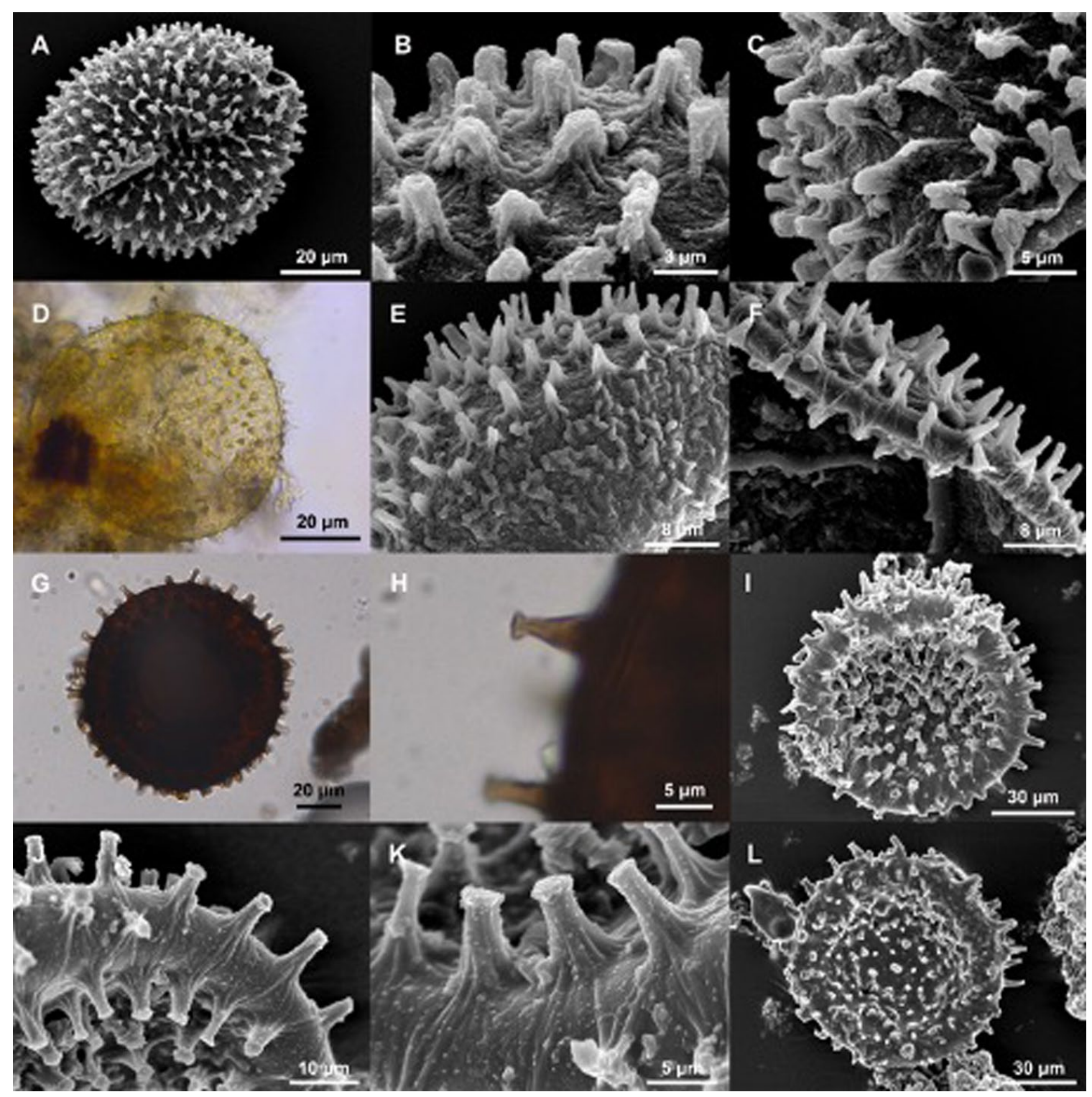

Fig. 4 Light and Scanning Electron Microscopy (SEM) images of fossil Riella spores from Iranian core sediments. A-C, Riella cossoniana. D-F. Riella echinata. G-L, Riella helicophylla. A, D, G, I, spores in distal view, L, spore in proximal view, B, C, E, F, H, J, K, detail of distal spines. A-C, E, F from Lake Urmia, D, from Parishan, $\mathbf{G}-\mathbf{L}$, from Hirom

\section{Discussion}

Each year, approximately 2000 new plant species are added to the flora of our planet, which is estimated by 2016 as $>374,000$ (Christenkusz and Byng 2016). These additions come mostly from biodiversity hotspots around the world (Joppa et al. 2011). In low latitudes in particular, most of the plant biodiversity is found in biodiversity hotspots coinciding with semi-arid mountain regions (Noroozi et al. 2019a). Many wetland systems found within these regions, sometimes called 'green islands', display a very high species richness and contain many endemic and relict species (Naqinezhad et al. 2009; Kidane et al. 2019). These wetland habitats are under serious threats by anthropogenic activities and global climate change and do not benefit from appropriate conservation management measures, primarily due to lack of data and documentation on their distribution and conservation status (Naqinezhad et al. 2019). 
The data presented in this paper demonstrates that Riella has played a significant role at least in Quaternary history of wetland flora of the Irano-Anatolian biodiversity hotspot. Thank to its morphologically characteristic and resistant spores, Riella seems to be one of the rare liverworts which ecological history can be traced back in lake and wetland sedimentary archives. Occurrence of Riella spores in topmost sediment layers of several sites, strongly suggest that it may be still thriving in some of these wetlands, and most probably in many other wetlands with analogous basin physiography and hydrology. Any attempt to discover Riella populations in situ necessitates the organisation of botanical field excursions at the right season and right place. However, sampling of soil sediments at promising sites for later laboratory cultures has proven a successful strategy (Segarra-Moragues and Puche 2014; Segarra-Moragues et al. 2019a). Recent progress in laboratory culture and the required physico-chemical conditions of spore germination provides unique opportunity to discover the species occurrence by cultivating the sediments taken from potentially suitable areas (Sabovljević et al. 2016). The combination of the two methods can thus, increase the possibilities to discover both new populations and species.

Wetland ecosystems of SW Asia, similar to many other wetland systems worldwide, are under threat by intensified human intervention exacerbated by current climate change (Junck et al. 2013). In Iran, many wetlands have been profoundly affected by recent global climate change but particularly mismanagement of water resources. Construction of many dams on the drainage basin of internal lake systems and wetlands e.g. Lake Urmia has caused the shrinkage and sometimes almost total desiccation of these ecosystems. In Lake Urmia region where vast alluvial plains and fluvio-lacustrine environments are home to an extremely rich biodiversity and endemism of halo-tolerant and halophytic species (Ghorbanalizadeh et al. 2020), the recent falling of water levels have caused the disappearance of many aquatic habitats. Many of these habitats are actually compatible with the ecological niches of Riella in the Mediterranean, including flat areas and shallow depressions seasonally flooded during spring time. The loss of such habitats is thus, catastrophic for many species, including those yet to be discovered and that would otherwise contribute to increase the biodiversity of the Irano-Anatolian hotspot.

Indeed, Riella is not the only hidden representative of the flora of Irano-Anatolian Biodiversity Hotspot. Three other examples are worth mentioning, all revealed through detailed morpho-taxonomic examination of subfossil pollen and macroremains in peat sediments. Two examples are from a late Holocene pollen and macrofossil record from a highaltitude peat bog (Lake Almalou, $2500 \mathrm{~m}$ ) in NW Iran (Djamali et al. 2009a). This record revealed a semi-continuous pollen curve for the carnivorous plant Drosera never reported alive from the Iranian flora. The youngest pollen grains of this plant in Almalou record date back to almost contemporaneous sediments. The pollen record further revealed a spore type described as HdV-31A identified as testate amoeba Archerella flavum (=Amphitrema flavum, see the official website of the Non-Pollen Palynomorphs: http://nonpollenp alynomorphs.tsu.ru/detail_type.html?Id=HdV-31A\&lang=ru-RU). This spore type is associated with the moss genera Meesia and Sphagnum (van Geel et al. 1989) suggesting that these moss genera were present in the Little Ice Age (LIA) in the region. None of these genera have then been reported alive for Iran. However, examination of the macroremains of the LIA aged interval actually revealed abundant Meesia triquetra Ångstr. remains a cool-temperate moss species considered as a 'glacial relict' in the flora of SW Asia (Kürschner and Djamali 2008). Another example of subfossil evidence of 'glacial relicts' is the Sphagnum squarrosum which macroremains have been reported all along a 2000-year long palaeoecological record from Tuska Tchal peat bog in northeastern Iran (Kürschner et al. 2015). Once again, the search for Sphagnum remains was stimulated by the finding of both 
spores and associated Non-Pollen Palynomorphs. Living populations of another species of Sphagnum, i.e. S. girgensohnii has recently been reported for the first time in Iran adding it to the modern bryophyte flora of Iran (Faridi and Amiri 2007).

The potential use of palaeoecology to discover new plant taxa has so far been paid less attention because most of the palaeoecological literature on wetlands is from Europe and North America, where the modern and fossil wetland flora are much better studied. At low latitude areas such as the Irano-Anatolian Biodiversity Hotspot, the floristic surveys of wetland systems are still in their exploratory phase (Naqinezhad et al. 2009) and can benefit from the palaeoecological insights to expose hidden species (Kürschner et al. 2015). Wetland palaeoecology can thus, contribute to better characterize the plant biodiversity (both vascular and non-vascular taxa) in wetland systems and aid botanists to design target-based explorations for undiscovered species. This is particularly helpful for those species such as Riella spp. which show population fluctuations with intervals of demographic blooms interrupted by intervals of total absence in the ecosystem, often for decades, (Studhalter 1932; Proctor 1972; Martinez et al. 2014). Their sporadic growth and ephemeral development make them hardly visible to field botanists. Among bryophytes, the liverworts have one of the best fossil records dating back to Palaeozoic time (Wellman et al. 2003). Such fossil records provide a unique opportunity to attribute absolute ages to nodes within their phylogenetic trees (Forrest et al. 2006). The possibility of precise taxonomic identifications of Riellaceae based on spore morphology (Segarra-Moragues et al. 2014) is particularly interesting in terms of future molecular dating of the phylogeny of the family which is still poorly known (but see Forrest et al. 2015). Riellaceae are mostly found in small shallow wetlands and seasonal temporary ponds with a rich fauna and flora adapted to harsh ephemeral conditions and cycles of flooding and desiccation (Gradstein 2016). Many plant and animal species of these environments may have been extirpated due to very recent intensification of anthropogenic activities. Palaeoecological investigation of their subsurface sediments can reveal the very recent occurrences and decline of such species, which is important if the restoration efforts are made, including their re-introduction (Buldrini et al. 2013). Botanical field excursions accompanied with surface sediment sampling for laboratory cultures and sub-surface coring for palaeobotanical search for past populations can together be a powerful tool to help discover the new habitats with recent past or presentday occurrence of Riella species. This will help better define the ecosystems of higher conservation priority.

\section{Conclusions}

Palaeoecology can be a complementary tool in the hands of biologists to reveal a hidden part of the biodiversity contained especially in biodiversity hotspots, the fauna and flora of which are still poorly known. For this, high taxonomic precision in fossil identifications is an asset to increase the chances to discover new species or new records. Recent sub-fossil records are of particular interest as there is an increased possibility that particular species are still thriving in a given ecosystem, when their traces are found in the recent past of that ecosystem.

Wetland systems at high elevations and temporary seasonal wetlands seem to be invaluable targets to use palaeoecology in combination with modern ecology in search for new species and records and provide excellent ground for collaboration between palaeoecologists and conservation biologists. Shallow wetlands with significant annual 
or interannual water-table fluctuations under seasonal Mediterranean climates seem to provide optimal conditions for the growth and thriving of the Riellaceae. Many of these environments are under serious threat by anthropogenic interventions exacerbated by global climatic change and may already have lost the last populations of these rare and endangered liverworts. Our detailed analysis of fossil spores from sediment cores, indicated that they could involve at least three species of Riella, with biogeographical implications for the genus. Botanical surveys complemented by late Holocene palaeoecological study of these environments can help to identify and then protect not only Riellaceae but also numerous other organisms adapted to their narrow ecological niches. Many Riella habitats are currently located in coastal areas and/or wetland systems of drylands, and are threatened by ground and surface water overexploitation, development of urban and industrial zones, and water pollution due to agricultural pesticides and fertilizers (Martínez et al. 2014). These ecosystems must be urgently pinpointed, ecologically characterized and subjected to ecological restoration in the light of the ecological and historical plaeoecological studies.

Supplementary Information The online version contains supplementary material available at https://doi. org/10.1007/s10531-021-02218-3.

Acknowledgements The palaeoecological records presented in this study were mostly produced through the financial support provided by "PALEO-PERSEPOLIS" project (2015-2019) funded by Agence Nationale de la Recherche (ANR-14-CE35-0026-01) and the international LIA project entitled "HAOMA" sponsored by Centre National de la Recherche Scientifique (CNRS). The authors wish to thank the thoughtful and constructive comments of the two anonymous reviewers of the manuscript.

Author contributions Authors have equally contributed to this research paper.

\section{References}

Aubert C, Djamali M, Jones M, Lahijani HAK, Marriner N, Naderi-Beni A, Sharifi A, Ponel P, Gandouin E (2019) A major hydrobiological change in Dasht-e Arjan Wetland (SW Iran) during the late glacialearly Holocene transition revealed by subfossil chironomids. Can J Earth Sci 56:848-856

Birks HJB (1993) Quaternary paleoecology and vegetation science: current contributions and possible future developments. Rev Palaeobot Palynol 79:153-177

Birks HJB (2012) Ecological palaeoecology and conservation biology: controversies, challenges, and compromises. Int J Biodivers Sci Ecosyst Serv Manage 8:292-304

Blaauw M (2010) Methods and code for "classical" age-modelling of radiocarbon sequences. Quaternary Geochronol 5:512-518

Brisset E, Djamali M, Bard E, Borschneck D, Gandouin E, Garcia M, Stevens L, Tachikawa K (2019) Late Holocene hydrology of Lake Maharlou, southwest Iran, inferred from high-resolution sedimentological and geochemical analyses. J Paleolimnol 61:111-128

Brugués M, González Mancebo JM (2014) Lista Roja de los briófitos amenazados de España. In: Garilleti R, Albertos B. (Coords.). Atlas de los briófitos amenazados de España. Universitat de València. http:// www.uv.es/abraesp

Buldrini F, Dallai D, Torri P (2013) Can palynology contribute to plant diversity conservation activities? The wetland plants in southern Po Plain as a case study. Annali Botanica 3:245-254

Campisi P, Cogoni A (2019) Riella mediterranea. The IUCN Red List of Threatened Species 2019: e.T84516595A87773338. Downloaded on 24 June 2020

Cargill DC, Milne J (2013) A new terrestrial genus and species within the aquatic liverwort family Riellaceae (Sphaerocarpales) from Australia. Pol Bot J 58:71-80 
Cavagnetto C, Anadón P (1996) Preliminary palynological data on floristic and climate changes during the Middle Eocene-Early Oligocene of the eastern Ebro Basin, northeast Spain. Rev Palaeobot Palynol 92:281-305

Cholo F, Foden W (2010a) Riella alatospora. IUCN Red List Threat Species 2010:e.T185470A8418003. https://doi.org/10.2305/IUCN.UK.2010-3.RLTS.T185470A8418003.en

Cholo F, Foden W (2010b) Riella capensis. IUCN Red List Threat Species 2010:e.T185382A8400284. https://doi.org/10.2305/IUCN.UK.2010-3.RLTS.T185382A8400284.en

Cholo F, Foden W (2010c) Riella echinospora. IUCN Red List Threat Species 2010:e.T185501A8424143. https://doi.org/10.2305/IUCN.UK.2010-3.RLTS.T185501A8424143.en

Cholo F, Foden W (2010d) Riella purpureospora. IUCN Red List Threat Species 2010:e.T185442A8412619. https://doi.org/10.2305/IUCN.UK.2010-3.RLTS.T185442A8412619.en

Coffey EED, Froyd CA, Willis KJ (2011) When is an invasive not an invasive? Macrofossil evidence of doubtful native plant species in the Galápagos Islands. Ecology 92:805-812

Djamali M, de Beaulieu J-L, Shah-Hosseini M, Andrieu-Ponel V, Amini A, AkhaniH LSAG, Stevens L, Alizadeh H, Ponel P, Brewer S (2008a) A late Pleistocene long pollen record from Lake Urmia, NW Iran. Quat Res 69:413-420

Djamali M, Kürschner H, Akhani H, de Beaulieu J-L, Amini A, Andrieu-Ponel V, Ponel P, Stevens L (2008b) Palaeoecological significance of the spores of the liverwort Riella (Riellaceae) in a late Pleistocene long pollen record from the hypersaline Lake Urmia, NW Iran. Rev Palaeobot Palynol 152:66-73

Djamali M, de Beaulieu J-L, Miller NF, Andrieu-Ponel V, Lak R, Sadeddin M, Akhani H, Fazeli H (2009a) Vegetation history of the SE section of Zagros Mountains during the last five millennia; a pollen record from the Maharlou Lake, Fars Province. Iran Veg Hist Archaeobot 18:123-136

Djamali M, de Beaulieu J-L, Miller N, Andrieu-Ponel V, Berberian M, Gandouin E, Lahijani H, Ponel P, Salimian M, Guiter F (2009b) A late Holocene pollen record from Lake Almalou in NW Iran: evidence for changing land-use in relation to some historical events during the last 3700 years. J Archaeol Sci 36:1346-1375

Djamali M, Akhani H, Khoshravesh R, Andrieu-Ponel V, Ponel P, Brewer S (2011) Application of the global bioclimatic classification to Iran: implications for understanding the modern vegetation and biogeography. Ecologia Mediterranea 37:91-114

Djamali M, Brewer S, Breckle S, Jackson ST (2012a) Climatic determinism in phytogeographic regionalization: a test from the Irano-Turanian region, SW and Central Asia. Flora 207:237-249

Djamali M, Baumel A, Brewer S, Jackson ST, Kadereit JW, López-Vinyallonga S, Mehregan I, Shabanian E, Simakova A (2012b) Ecological implications of Cousinia Cass. (Asteraceae) persistence through the last two glacial-interglacial cycles in the continental Middle East for the Irano-Turanian flora. Rev Palaeobot Palynol 72:10-20

Djamali M, Jones MD, Migliore J, Balatti S, Fader M, Contreras D, Gondet S, Hosseini Z, Lahijani H, Naderi-Beni A, Shumilovskikh LS, Tengberg M, Weeks L (2015) Olive cultivation in the heart of the Persian Achaemenid Empire: new insights to agricultural practices and environmental changes reflected in a late Holocene pollen record from Lake Parishan, SW Iran. Veg Hist Archaeobot 25:255-269

Djamali M, Gondet S, Ashjari J, Aubert C, Brisset E, Longerey J, Marriner N, Mashkour M, Millet NF, Naderi-Beni A, Pourkerman M, Rashidian E, Rigot J-B, Shidrang S, Thiéry A, Gandouin E (2018) Karstic-spring wetlands of the Persepolis Basin, SW Iran: unique sediment archives of Holocene change and human impact. Can J Earth Sci 55:1158-1172

Faridi M, AMIRI AA (2007) New moss genera for the moss flora f Iran. - 7th Plant Life of South West Asia Symposium, Program book of abstracts and participant list, P-70. - Eskişehir

Forrest LL, Davis C, Long DG, Crandall-Stotler BJ, Clark A, Hollingsworth L (2006) Unraveling the evolutionary history of the liverworts (Marchantiophyta): multiple taxa, genomes and analyses. Bryol 109:303-334

Forrest LL, Long DG, Cargill DC, Hart ML, Milne J, Schill DB, Seppelt RD, Villarreal JC (2015) On Monocarpus (Monocarpaceae, Marchantiopsida), an isolated salt-pan complex thalloid liverwort. Aust Syst Bot 28:137-144

Frey W, Probst W (1974) Vegetationszonierung an Süsswasserquellen des Maharlu-Salzsees bei Shiraz (Iran). Vegetatio 29:109-114

Froyd CA, Willis KJ (2008) Emerging issues in biodiversity and conservation management: the need for a palaeoecological perspective. Quat Sci Rev 27:1723-1732

Garilleti R, Albertos B (2012) Atlas y Libro Rojo de los Briófitos Amenazados de España. organismo Autónomo Parques Nacionales, Madrid 
Geissler P (2001) The phytogeography of Mediterranean bryophytes: progress and problems. Bocconea 13:81-88

Ghorbanalizadeh A, Akhani H, Bergmeier E (2020) Vegetation patterns of a rapidly drying up salt lake ecosystem: Lake Urmia, NW Iran. Phytocoenologia 50:1-46

Gradstein SR (2016) Amphitropical disjunctive species in the complex thalloid liverworts (Marchantiidae). J Bryol 39:66-78

Guijarro JA (2019) Package 'climatol': climate tools (series homogenization and derived products). https://cran.r-project.org/web/packages/climatol/index.html

Hosseini Z, Khaledi S, Naderi-Beni A (2017) Reconstruction of vegetation and palaeoclimate of Dasht-e Arjan, Fars, during the late Pleistocene and Holocene based on pollen analysis. J Climatol Studies 27-28:87-98 (Persian language)

Jackson ST (1997) Documenting natural and human-caused plant invasions using paleoecological methods. In: Luken JO, Thieret JW (eds) Assessment and management of plant invasions. Springer, Berlin, pp 37-55

Jackson ST, Hobbs RJ (2009) Ecological restoration in the light of ecological history. Science 325:567-569

Jackson ST, Overpeck JT (2000) Responses of plant populations and communities to environmental changes of the late Quaternary. Paleobiol 26:194-220

Jones MD, Djamali M, Holmes J, Weeks L, Leng MJ, Lashkari A, Alamdari K, Noorollahi A, Thomas L, Metcalfe SE (2015) Human impact on the hydroenvironment of Lake Parishan, SW Iran, through the late Holocene. Holocene 25:1651-1661

Joppa LN, Roberts DL, Myers N, Pimm SL (2011) Biodiversity hotspots house most undiscovered plant species. PNAS 108:12171-12176

Kidane YO, Steinbauer MJ, Beierkuhnlein C (2019) Deae end for endemic plant species? A biodiversity hotspot under pressure. Glob Ecol Conserv 19:e00670

Krinsley D (1970) Geomorphological and paleoclimatological study of the playas of Iran. Geological Survey, United States Department of Interior, Washington

Kürschner H, Djamali M (2008) Meesia Hedw. (Meesiaceae, Bryophyta) in Iran-evidence from a Quaternary subfossil record. Nova Hedwigia 87:501-508

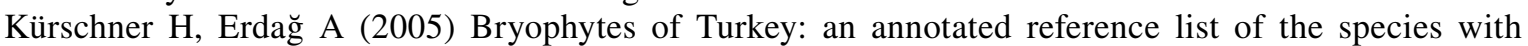
synonyms from the recent literature and an annotated list of Turkish bryological literature. Turk J Bot 29:95-154

Kürschner H, Shumilovskikh L, Djamali M, de Beaulieu J-L (2015) A late Holocene subfossil record of Sphagnum squarrosum Crome (Sphagnopsida, Bryophyta) from NW Iran. Nova Hedwigia 100:373-381

Lipkin Y, Proctor VW (1975) Notes on the subgenus Trabutiella of the aquatic liverwort Riella (Riellaceae, Sphaerocarpales). Bryol 78:25-31

Manafzadeh S, Staedler YM, Conti E (2016) Visions of the past and dreams of the future in the Orient: the Irano-Turanian region from classical botany to evolutionary studies. Biol Rev Camb Philos Soc 92:1365-1388

Manzano S, Carrión JS, López-Merino L, Ochando J, Munuera M, Fernández S, González-Sampériz P (2018) Early to mid-Holocene spatiotemporal vegetation changes and tsunami impact in a paradigmatic coastal transitional system (Doñana National Park, southwestern Europe). Glob Planet Change 161:66-81

Martinez L, Grillas P, Offerhaus B, Puche F, Segarra-moragues J (2014) Riella cossoniana Trab. (Riellaceae, Marchantioophyta) new to France. Cryptogam Bryol 35:197-210

Mehterian S, Pourmand A, Sharifi A, Lahijani HAK, Naderi M, Swart PK (2017) Speleothem records of glacial/interglacial climate from Iran forewarn of future water availability in the interior of the Middle East. Quat Sci Rev 164:187-198

Miehe G, Miehe S, Schültz F, Kaiser K, Duo L (2006) Palaeoecological and experimental evidence of former forests and woodlands in the treeless desert pastures of Southern Tibet (Lhasa, A.R. Xizang, China). Palaeogeogr Palaeoclimatol Palaeoecol 242:54-67

Moore PD, Webb JA, Collinson ME (1991) Pollen analysis, 2nd edn. Blackwell, Oxford

Mousaei-Sanjerani M, Rundel PW (2016) The future of Iranian wetlands under climate change. Wetlands Ecol Manage 25:257-273

Munnia V (2019). Analyse palynologique d'une séquence sédimentologique provenant du site du Pasargades (Iran). Unpublished Master (M1) thesis in Archaeology, l'Université Lumière Lyon 2, Lyon.

Naqinezhad A, Jalili A, Attar F, Ghahreman A, Wheeler BD, Hodgson JG, Shaw SC, Maassoumi A (2009) Floristic characteristics of the wetland sites on dry southern slopes of the Alborz Mts., N. Iran: the role of altitude in floristic composition. Flora 204:254-269 
Naqinezhad A, Ramezani E, Khalili AH, Joosten H (2019) Habitat and floristic peculiarities of an isolated mountain mire in the Hyrcanian region of northern Iran: a harbour for rare and endangered plant species. Mires and Peat 24:1-22

Noroozi J, Naqinezhad A, Talebi A, Doostmohammadi M, Plutzar C, Rumpf SB, Asgharpour Z, Schneeweiss GM (2019) Hotspots of vascular plant endemism in a global biodiversity hotspot in Southwest Asia suffer from significant conservation gaps. Biol Conserv 237:299-307

Noroozi J, Talebi A, Doostmohammadi M, Manafzadeh S, Asgharpour Z, Schneeweiss GM (2019) Endemic diversity and distribution of the Iranian vascular flora across phytogeographical regions, biodiversity hotspots and areas of endemism. Sci Rep 9:12991

Prieto AR, Quattrocchio ME (1993) Briofitas y pteridofitas en sedimentos del Holoceno de la Provincia de Buenos Aires, Argentina. Anales De La Asociación Palinológica De La Lengua Española 6:17-37

Proctor VW (1972) The genus Riella in North and South America: distribution, culture and reproductive isolation. The Bryologist 75:281-289

Puche F, Segarra-Moragues JG (2013) Riella bialata Trab. (Riellaceae, Marchantiophyta): a new addition to the European liverwort flora. Cryptogam Bryol 34:341-352

Quattrocchio M, Durango de Cabrera J, Galli C (2003) Formación anta (mioceno temprano/medio), subgrupoMetán (grupoorán), en el río piedras, pcia. de salta, datos palinológicos. Rev de la Asoc Geol Argent 58:117-127

Rivas-Martínez S, Rivas Sáez S, Penas A (2005) Worldwide bioclimatic classification system. Glob Geobot $1: 1-634$

RStudio Team (2015) RStudio: Integrated Development for R. RStudio, Inc., Boston, MA. http://www.rstud io.com/

Sabovljević MS, Segarra-Moragues JG, Puche F, Vujičić M, Cogoni A, Sabovljević A (2016) An eco-physiological and biotechnological approach to conservation of the world-wide rare and endangered aquatic liverwort Riella helicophylla (Bory et Mont.) Mont. Act Bot Croat 75:194-198

Saeidi Ghavi Andam S, Djamali M, Nelle O, Naderi-Beni M, Haghighifard M, Brisset E, Poschlod P (2020) Vegetation history of Maharlou Lake basin (SW Iran) with special reference to Achaemenid period (550-330 B.C.). Veg Hist Archaeobot. https://doi.org/10.1007/s00334-020-00810-1

Segarra-Moragues JG, Puche F (2014) Advances in the knowledge of South African Riella (Sphaerocarpales) and a new endemic species, Riella trigonospora. S Afr J Bot 94:166-176

Segarra-Moragues JG, Puche F, Sabovljevic M (2012) Riella heliospora (Riellaceae) a new monoicous species of Riella subgenuc Trabutiella from California. Syst Bot 37:307-319

Segarra-Moragues JG, Puche F, Sabovljevic M, Infante M, Heras P (2014) Taxonomic revision of Riella subgenus Trabutiella (Riellaceae, Sphaerocarpales). Phytotaxa 159:131-174

Segarra-Moragues JG, Puche F, Gleiser G (2019) Study of a new population of the Argentinian endemic species Riella choconensis Hässel (Riellaceae, Marchantiophyta) reveals a novel anatomical structure of the female involucre in Riella. Cryptogam Bryol 40:131-140

Segarra-Moragues JG, Puche F, Gil-López MJ (2019) A complete description and conservation assessment of Riella affinis Howe \& Underwood (Riellaceae, Sphaerocarpales) new to continental Europe. Cryptogam Bryol 40:297-307

Sérgio C, Puche F (2019a) Riella helicophylla. IUCN Red List Threat Species 2019:e.T84516558A87730718

Sérgio C, Puche F (2019b) Riella notarisii. IUCN Red List Threat Species 2019:e.T84516656A87730732

Sérgio C, Puche F (2019c) Riella parisii. IUCN Red List Threat Species 2019:e.T84516669A87730771

Sérgio C, Puche F (2019d) Riella echinata. IUCN Red List Threat Species 2019:e.T109636512A109636538

Sérgio C, Bergamini A, Garcia C, Garilleti R, Infante M, Porley RD, Puche F, Segarra-Moragues JG (2019a) Riella bialata. IUCN Red List Threat Species 2019:e.T84516325A87730687

Sérgio C, Bergamini A, Garcia C, Garilleti R, Infante M, Porley RD, Puche F, Segarra-Moragues JG (2019b) Riella cossoniana. IUCN Red List Threat Species 2019:e.T84516489A87730710

Söderström L, Hagborg A, Von Konrat M, Bartholomew- Began S, Bell D, Briscoe L, Brown E, Cargill DC, Costa DP, Crandall-Stotler BJ, Cooper ED, Dauphin G, Engel JJ, Feldberg K, Glenny D, Gradstein SR, He X, Ilkiu-Borges AL, Heinrichs J, Hentschel J, Katagiri T, Konstantinova NA, Larraín J, Long DG, Nebel M, Pócs T, Puche F, Reiner-Drehwald ME, Renner MAM, Sass-Gyarmati A, Schäfer-Verwimp A, Segarra Moragues JG, Stotler RE, Sukkharak P, Thiers BM, Uribe J, Váňa J, Villarreal JC, Wigginton M, Zhang L, Zhu R-L (2016) World checklist of hornworts and liverworts. Phytokeys 59:1-828

Stockmarr J (1971) Tablets with spores used in absolute pollen analysis. Pollen Spores 13:615-621

Studhalter RA (1932) The elusive ruffle plant, Riella. Sci Mon 35:303-311

Talebi T, Ramezani E, Djamali M, Lahijani HAK, Naqinezhad A, Andrieu-Ponel V (2016) The Late-Holocene climate change, vegetation dynamics, lake-level changes and anthropogenic impacts in the Lake Urmia region, NW Iran. Quat Int 408:40-51 
Threatened Bryophyte Advisory Group (2015) Proposed Red List of threatened bryophytes in Australia: extinct species (EX, EW, RE). Aust Bryol Newslett 65:17-19

Uchupi E, Swift SA, Ross DA (1999) Late Quaternary stratigraphy, paleoclimate and neotectonism of the Persian (Arabian) Gulf region. Mar Geol 160:1-23

van Geel B, Coope GR, van der Hammen T (1989) Palaeoecology and stratigraphy of the Lateglacial type section at Usselo (The Netherlands). Rev Palaeobot Palynol 60:25-129

van Leeuwen JFN, Froyd CA, van der Knaap WO, Coffey EED, Tye A, Willis KJ (2008) Fossil pollen as a guide to conservation in the Galápagos. Science 322:1206

Wellman CH, Osterloff PL, Mohiuddin U (2003) Fragments of the earliest land plants. Nature 425:282-285

Willis KJ, Birks HJB (2006) What is natural? The need for a long-term perspective in biodiversity conservation. Science 314:1261-1265

Willis KJ, Bailey RM, Bhagwat SA, Birks HJB (2010) Biodiversity baselines, thresholds and resilience: testing predictions and assumptions using palaeoecological data. Trends in Ecol Evol 25:583-591

Wingard GL, Bernhardt CE, Wachnicka H (2017) The role of paleoecology in restoration and resource management - the past as a guide to future decision-making: review and example from the Greater Everglades Ecosystem, U.S.A. Front Ecol Evol 5:1-24

Zohary M (1973) Geobotanical Foundations of the Middle East, vol I and II. Gustav Fischer Verlag, Amsterdam 